\title{
BY-PLANT PREDICTION OF CORN (Zea mays L.) GRAIN YIELD USING HEIGHT AND STALK DIAMETER
}

\author{
By \\ JONATHAN P. KELLY \\ Bachelor of Science in Plant and Soil Sciences \\ Oklahoma State University \\ Stillwater, OK \\ 2009
}

Submitted to the Faculty of the

Graduate College of the

Oklahoma State University in partial fulfillment of the requirements for the Degree of

MASTER OF SCIENCE

May, 2011 


\section{BY PLANT PREDICTION OF CORN (Zea mays L.) GRAIN YIELD USING HEIGHT AND STALK DIAMETER}

Thesis Approved:

Dr. William Raun

Thesis Adviser

Dr. Randy Taylor

Dr. Kefyalew Desta

Dr. Mark E. Payton

Dean of the Graduate College 


\section{ACKNOWLEDGMENTS}

This thesis would not have been possible without the guidance and the help of several individuals who in one way or another contributed their valuable assistance in the preparation and completion of this study.

I would like to first thank Dr. Bill Raun for the opportunity to work under his guidance, and all the knowledge that he has imparted to me. I would also like to thank the members of my graduate committee Dr. Kefyalew Desta and Dr. Randy Taylor for their guidance and suggestions. Also, I would like to express my appreciation for the individuals involved in the Soil Fertility Project; Jake Vossenkemper, Guilherme Torres, Katy Butchee, Yumiko Kanke, Jerry May, Daniel Edmonds, Bee Khim Chim, Jared Crain, Emily Rutto, Jeremiah Mullock, Kevin Waldschmidt, and Natasha MacNack.

I acknowledge the Oklahoma State University and Department of Plant and Soil

Science for giving me the opportunity to pursue this degree. Last but not least, I want to thank Mika Warren for her constant encouragement and support while working on this project. 
TABLE OF CONTENTS

Chapter

Page

I. ABSTRACT AND INTRODUCTION 1

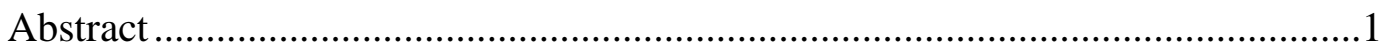

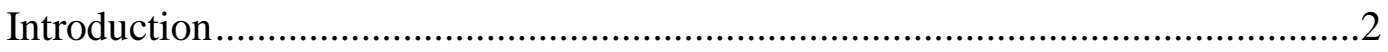

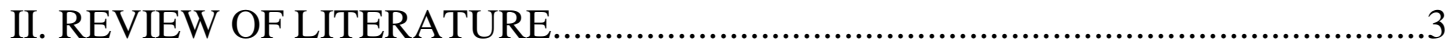

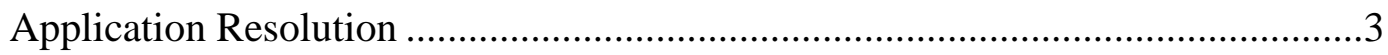

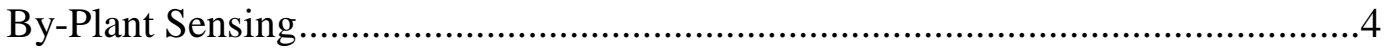

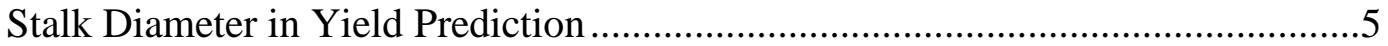

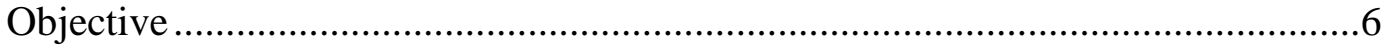

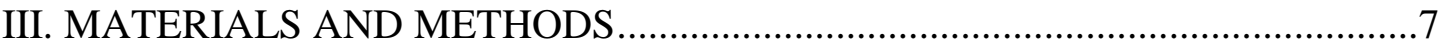

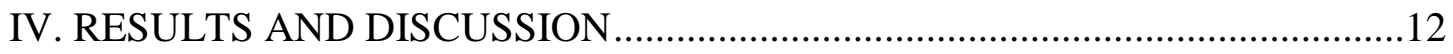

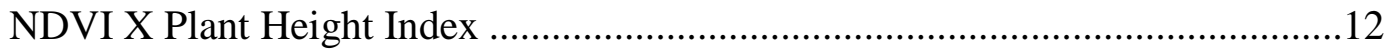

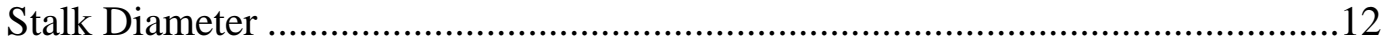

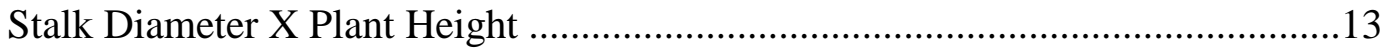

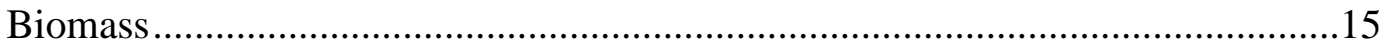

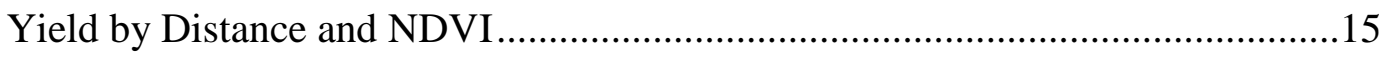

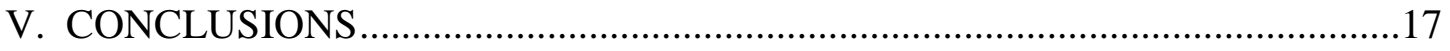

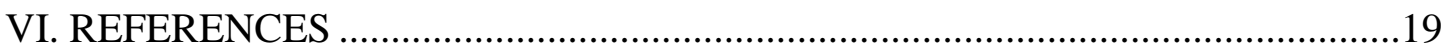

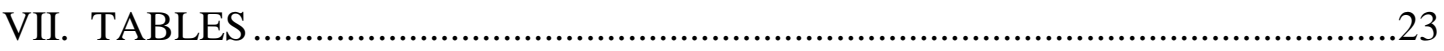

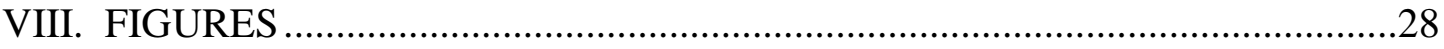




\section{LIST OF TABLES}

Table

1. Planting and harvest dates, growth stages, days after planting, (DAP), growing degree days (GDD), and plant population of corn rows used for stalk diameter, height, and sensor measurements at Lake Carl Blackwell (LCB, irrigated), Haskell, Efaw, OK, and Ciudad Obregón, Mexico, 20092011

2. Average total rainfall and temperature during corn growing months at Lake Carl Blackwell, Efaw, and Haskell, 2009 and 2010

3. Summary statistics for plant height, stalk diameter, and NDVI measurements at growth stages V8, V10, V12, and VT, averaged over sites and years

4. Linear relationship between by-plant grain yield and measured plant height, stalk diameter, and NDVI, at V8, V10, V12, and VT corn growth stages, averaged across locations and years in Oklahoma, and polynomial relationship between by plant biomass and stalk diameter in Mexico, V15, 2011

5. Relationship of NDVI X plant height, plant height, stalk diameter, stalk diameter $X$ height, and NDVI to by-plant corn grain yield, for growth stages V8, V10, V12, VT, and growth stage groups V8-V10, V10-V12, and V12VT, averaged over sites and years 


\section{LIST OF FIGURES}

Figure

Page

1. Relationship between stalk diameter and by-plant corn grain yield for growth stage V10-V12, Haskell and Lake Carl Blackwell, 2009-2010 .28

2. Relationship between stalk diameter and by-plant corn grain yield, growth stages V12-VT, Haskell and Lake Carl Blackwell, 2009-2010

3. Relationship between stalk diameter and by-plant corn grain yield, growth stages V8-V10, Haskell, Lake Carl Blackwell, and Efaw, 2009 and 2010

4. Relationship between stalk diameter and by-plant corn grain yield at growth stage V12, Lake Carl Blackwell, 2010

5. Relationship between stalk diameter $X$ plant height and by-plant corn grain yield, growth stages V10-V12, Haskell and Lake Carl Blackwell, 2009-2010..32

6. Relationship between stalk diameter and by-plant corn grain yield for growth stage V10, Haskell, 2009-2010.

7. Relationship between stalk diameter X plant height and by-plant corn grain yield, growth stages V8 to V10, Efaw, Lake Carl Blackwell, and Haskell, 2009 and 2010.

8. Relationship between stalk diameter $X$ plant height and by-plant corn grain yield, growth stage V8, Haskell, Lake Carl Blackwell, and Efaw, 2009 and 2010 .

9. Relationship between stalk diameter $X$ height and by-plant corn grain yield, growth stages V12 to VT, Haskell and Lake Carl Blackwell, 2009-2010.

10. Relationship between stalk diameter $X$ plant height and by-plant corn grain yield, growth stage V12, Lake Carl Blackwell, 2010.

11. Relationship between stalk diameter and by-plant corn biomass, growth stage V15, Ciudad Obregón, Mexico, 2011 
Figure

12. Stalk diameter $X$ plant height in top graph, and NDVI in bottom graph, as compared to by-plant corn grain yield by distance down the row. Lake Carl

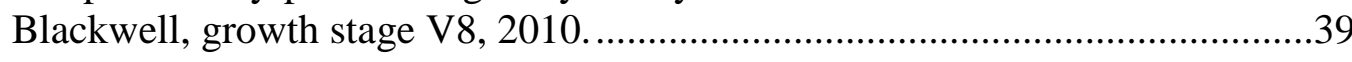

13. Stalk diameter X plant height in top graph, and NDVI in bottom graph, as compared to by-plant corn grain yield by distance down the row. Haskell, growth stage V10, 2010 


\section{CHAPTER I}

\section{ABSTRACT \& INTRODUCTION}

\section{Abstract}

Current methods for determining midseason nitrogen $(\mathrm{N})$ rates in corn have used normalized difference vegetation index (NDVI), and in some cases, plant height and intra-specific plant competition. Another parameter that can be linked to potential yield is stalk diameter; thus incorporating collectively the parameters of NDVI, plant height, and stalk diameter should result in a better prediction of yield potential. This could lead to more efficient methods for midseason fertilizer $\mathrm{N}$ applications. The objective of this study was to analyze the relationship of stalk diameter, as well as plant height and NDVI, with final grain yield, and to refine the method of predicting yield potential using a combination of these factors. In this 2 -year study at 4 locations, we selected several rows of corn plants, each with varying amounts of pre-plant nitrogen fertilizer, from 0 to 145 $\mathrm{kg} \mathrm{ha}^{-1}$, and where no additional nitrogen was applied throughout the growing season. Measurements of plant spacing, stalk diameter, plant height, and NDVI were taken from growth stages V8 (eight fully collared leaves) to VT (corn tasselling), and all corn plants were harvested by-plant to determine grain yield or dry biomass. Individual plant height measurements proved to be a good predictor of by-plant grain yield $\left(r^{2}=0.52,0.53 ; \mathrm{V} 10\right.$, V12, respectively). Using a value of stalk diameter X plant height gave the best correlation with grain yield $\left(r^{2}=0.34,0.55,0.67 ; \mathrm{V} 8, \mathrm{~V} 10, \mathrm{~V} 12\right.$, respectively). By-plant biomass was also highly correlated with stalk diameter, with an $r^{2}$ of 0.68 at growth stage V15, using a polynomial function. This work showed that stalk diameter X plant height 
was highly correlated with by-plant corn grain yields, and this parameter could possibly be used for refining midseason fertilizer $\mathrm{N}$ rates from growth stages V8 to V12.

\section{Introduction}

It has been estimated that worldwide Nitrogen Use Efficiency (NUE) of applied nitrogen fertilizers is about $33 \%\{\mathrm{NUE}=[($ total cereal $\mathrm{N}$ removed $)-(\mathrm{N}$ coming from the soil + N deposited in the rainfall)] / (fertilizer $\mathrm{N}$ applied to cereals) $\}$ (Raun and Johnson, 1999). Nitrogen use efficiency rates are very low because of several environmental factors, including leaching of $\mathrm{N}$ through the soil profile, ammonia volatilization, denitrification, and plant $\mathrm{N}$ losses as $\mathrm{NH}_{3}$ (Raun and Johnson, 1999; Raun et al., 1997). Current nitrogen management practices for corn production in the United States are largely inefficient, and are commonly blamed for the eutrophic "Dead Zone" at the mouth of the Mississippi River Delta in the Gulf of Mexico. It is estimated that more than $\$ 750,000,000$ worth of excess $\mathrm{N}$ annually flows down the Mississippi River into the Gulf of Mexico (Malakoff, 1998).

Because of this extensive misuse of $\mathrm{N}$ fertilizer, there is a pronounced need in the United States, as well as worldwide, to increase NUE among cereal crops, especially corn. Several methods can be used to improve NUE worldwide, including selection of better hybrids or cultivars, conservation tillage, $\mathrm{NH}_{4}-\mathrm{N}$ source, in-season and foliarapplied N, irrigation, or the application of precision agriculture (Raun and Johnson,1999). Precision agriculture is defined as a "management strategy that employs detailed, sitespecific information to precisely manage production inputs" (Searcy, 1997). This paper examines the possible use of physiological measurements, such as stalk diameter and plant height, as a method of predicting corn grain yield in order to precisely manage $\mathrm{N}$ fertilizer inputs. 


\section{CHAPTER II}

\section{LITERATURE REVIEW}

\section{Application Resolution}

Common $\mathrm{N}$ management practices often implement a field element size of the entire field in question, and $\mathrm{N}$ rates are often applied at a flat rate across an entire field. At best, zone or grid management systems are used to match $\mathrm{N}$ rates to a smaller field element size, which can be 0.2 to 4 or more hectares in size. However, significant soil test and biomass differences have been detected at resolutions equal to or less than $1 \mathrm{~m}^{2}$ (Solie et al., 1996; Raun and Johnson, 1999). When considered on a by-plant basis, Martin et al. (2005) found that significant variability in by-plant corn yields can be expected in distances less than $0.5 \mathrm{~m}$. Raun et al. (1998) and Solie et al. (1999) found significant soil test differences of $\mathrm{N}, \mathrm{P}$, and $\mathrm{K}$ values within resolutions of less than $1 \mathrm{~m}^{2}$ in $0.3 \times 0.3 \mathrm{~m}$ bermudagrass plots.

With these findings of variability within a resolution size often less than $1 \mathrm{~m}^{2}$, it would make sense that agricultural inputs, especially fertilizers, should be variably applied as needed at those resolutions in which differences are shown. However, soil sampling of an entire field at a resolution of $1 \mathrm{~m}^{2}$ would be cost-prohibitive, and therefore, other methods of variable rate applications must be considered. One of the most promising applications of applying fertilizers at such a small resolution size 
is that of using optical sensors to make the recommendation based on yield potential. Active sensors, such as the GreenSeeker® sensor, have been successfully used to make variable-rate applications of $\mathrm{N}$ fertilizer at a resolution of $0.4 \mathrm{~m}^{2}$ (Raun, 2010). Teal et al. (2004) noted that NUE can increase over $10 \%$ in corn and $15 \%$ in winter wheat using mid-season $\mathrm{N}$ fertilizer rates based on predicted yield potential and a response index system, such as those used by Oklahoma State University.

\section{By-Plant Sensing}

By-plant variability in corn yields is well-documented (Martin et al., 2005; Teal, 2004; Freeman et al., 2007), expressing the need for management of $\mathrm{N}$ on a by-plant basis for corn. A study by Freeman et al. (2007) revealed that NDVI, along with plant height measurements, can be used to predict by-plant corn forage yield. This study found that an index of NDVI X plant height had a strong relationship $\left(r^{2}=0.77\right)$ with $\mathrm{N}$ uptake from V10 to R1 growth stages (Freeman et al., 2007). Additionally, Freeman et al. (2007) found that plant height alone was a strong predictor $\left(r^{2}=0.81\right)$ of dry plant biomass at growth stages V8-V10.

Other studies (Martin et al. 2007; Teal et al. 2007; Raun et al., 2005) have shown that the coefficient of variation (CV) from NDVI measurements taken down the row varies widely throughout the growing season. Martin et al. (2007) and Raun et al. (2005) showed that CV's of NDVI measurements were highest in corn from growth stages V6V8, and lowest from V10-VT. Variability within the plants were expressed most during the V6 to V8 growth stages, because larger plants started covering the rows, and smaller plants still allowed bare soil to be measured in the NDVI readings; thus indicating a higher CV of NDVI measurements at these growth stages. However, from V10 to VT, 
the plants were larger, more uniform, and had more complete canopy closure. This allowed the $\mathrm{CV}$ of NDVI measurements to reach its lowest point. Because of these findings, it is possible that NDVI alone could be used to predict by-plant corn yield potential at the earlier growth stages of V6 to V8. However, from V10 on to VT, using NDVI alone should not be as successful in determining by-plant yield potential, because it will be impossible to distinguish individual plants due to leaf canopy closure.

\section{Stalk Diameter in Yield Prediction}

With the findings of Martin et al. (2007) using the CV of NDVI values in corn, and the positive relationship of using a NDVI X plant height index for predicting yield potential (Freeman et al., 2007), it is evident that in order for by-plant yield estimation in corn to be successful, other plant characteristic measurements need to be included with NDVI measurements. Other factors which may be considered are corn stalk diameter, area occupied by the individual plants, and competition factors among corn plants. Shaw and Loomis (1950) showed that correlation of stalk diameter to final corn grain yield is variable, depending on environmental conditions, and showed that both stalk height and diameter were subject to differences among corn varieties. Another study by Pordesimo et al. (2004) showed that regression equations using both stalk diameter and height may be used to predict both fresh and dry weight of corn stover, resulting in a maximum $r^{2}$ value of 0.76 . With regard to stalk diameter only, a study by Jones et al. (1995) showed

that stalk diameter increased with increasing $\mathrm{N}$ rates, from 0 to $180 \mathrm{~kg} \mathrm{ha}^{-1}$, but decreased with an increase in plant density. Sorensen et al. (2006) studied the effects of single- and twin-row planting methods and planting densities on grain yield, test weight, and stalk diameter. They found no difference in stalk diameter and grain yield between single- and 
twin-row planting at the same population, but there was a difference in stalk diameter and grain yield between single- and twin-row plantings of the same population and a twinrow planting of two times the population. This suggests that as corn planting density increases to a certain amount, stalk diameters and final grain yields decrease. Based on this conflicting information, this study was carried out to determine if stalk diameter could be used to predict yield.

Normalized difference vegetation index, plant height, plant density, and stalk diameter are all factors that play a role in final corn grain yield. A better understanding of these factors may help to predict yield potential in corn, and thus help in determining the optimum $\mathrm{N}$ rates for better mid-season $\mathrm{N}$ application. This could possibly lead to an increase in NUE in corn production in the U. S., as well as worldwide.

\section{Objective}

The objective of this study was to determine the relationship of stalk diameter, plant height, and NDVI measurements, with final corn grain yield. 


\section{CHAPTER III}

\section{MATERIALS AND METHODS}

Experimental Sites were established at the R. L. Westerman Irrigation Research Center, Lake Carl Blackwell, near Stillwater, OK, and the Eastern Research Station, near Haskell, OK, for the years 2009 and 2010. Another location was added for spring 2010 at the Efaw site of the Stillwater Agronomy Research Station, and an additional location in Ciudad Obregón, Mexico was added in 2011. The site at the R. L. Westerman Irrigation Research Center was irrigated, and is located on a Pulaski fine sandy loam (coarse loamy, mixed, superactive, nonacid, Udic Ustifluvent). The Efaw site was located on a Norge loam, 3 to 5 percent slope, eroded (fine-silty, mixed, active, thermic Udic Paleustolls), while the site at the Eastern Research Station was located on a Taloka silt loam, 1 to 3 percent slope (fine, mixed, active, thermic Mollic Albaqualfs). All locations were planted to corn (Zea mays L.) with a John Deere MaxEmerge 2, four-row vacuum planter, with a row spacing of $0.76 \mathrm{~m}$. The Haskell and Efaw locations were dry-land locations planted at a targeted population of 61,775 seeds ha $^{-1}$ and 49,667 seeds $\mathrm{ha}^{-1}$, respectively, while the irrigated site was planted at a target population of 85,000 seeds $\mathrm{ha}^{-1}$ (Table 1). The location in Mexico had a seeding rate of 67,700 seeds ha ${ }^{-1}$. Two years of data were taken from the Haskell and the LCB irrigated sites, one year at the Efaw site, and one year at the Ciudad Obregón, Mexico site for a total of 6 site-years. 
Four rows of corn $6.1 \mathrm{~m}$ long were selected within an existing trial at each location in Oklahoma with different pre-plant $\mathrm{N}$ rates (no top-dress $\mathrm{N}$ applied). Five rows of corn $12 \mathrm{~m}$ long and $0.8 \mathrm{~m}$ row spacing were selected at the Mexico site. The preplant $\mathrm{N}$ rates were $0,45,90$, and $180 \mathrm{~kg} \mathrm{~N} h^{-1}$ in Oklahoma, and 35, 70, and $245 \mathrm{~kg} \mathrm{~N}$ $\mathrm{ha}^{-1}$ in Mexico, and were applied merely to effect a change in the measurements taken. Even though this experiment was located inside of a replicated field trial, treatments were not applied and replications not considered because each plant was analyzed with yield individually. Phosphorus and potassium levels were applied based on a sufficiency level according to Oklahoma State University Department of Plant and Soil Sciences guidelines for respective locations. Weed control was achieved via pre-emergence herbicide and mid-season application of glyphosate. Within each row, the distance down the row from a pre-determined point was recorded, and each plant was tagged with a unique identifying tag. At growth stages V8 ( $8^{\text {th }}$ leaf collar unfolded), V10 $\left(10^{\text {th }}\right.$ leaf collar unfolded), V12 (12 ${ }^{\text {th }}$ leaf collar unfolded), and VT (last branch of tassel visible) (Ritchie et al., 1996), plant height, NDVI, and stalk diameter were taken from each tagged plant within the selected row. These growth stages were chosen because most mid-season $\mathrm{N}$ application will take place prior to V10. Therefore, yield prediction possibilities were examined before and after this point. Plant height was taken by measuring the height from the soil surface to the top arch of the uppermost leaf that is more than 50\% emerged from the whorl (Hager, 2010). Stalk diameter was taken using a digital caliper, with measurements collected on the major (widest part of stalk) and minor (thinnest part of stalk) axes $10 \mathrm{~cm}$ above the soil surface in an internodal area of the corn stalk. 
Normalized difference vegetation index values from each plant were taken using a bicycle-mounted GreenSeeker Hand Held sensor (Trimble Navigation, Sunnyvale, CA) with a shaft encoder that recorded NDVI every centimeter of linear distance down the row. The GreenSeeker Hand Held unit measures NDVI in a 0.6 by $0.01 \mathrm{~m}$ area when held 0.6 to $1.0 \mathrm{~m}$ above the crop canopy. The sensor contains a self illuminated light source in the red $(650 \pm 10 \mathrm{~nm})$ and near infrared (NIR, $770 \pm 15 \mathrm{~nm})$ bandwidths (Freeman et al., 2007). The GreenSeeker calculates NDVI as follows:

$$
\text { NDVI }=\left(\rho_{\mathrm{NIR}}-\rho_{\mathrm{red}}\right) /\left(\rho_{\mathrm{NIR}}-\rho_{\mathrm{red}}\right),
$$

Where $\rho_{\mathrm{NIR}}=$ the fraction of emitted NIR radiation returned from the sensed area (reflectance), and $\rho_{\mathrm{red}}=$ the fraction of emitted red radiation returned from the sensed area (reflectance). The bicycle-mounted GreenSeeker was pushed down the middle of the corn rows, while the sensor maintained a position centered over the row at about $0.9 \mathrm{~m}$ above crop canopy, and travelled parallel to the row. The GreenSeeker was situated over the row in a way where the light emitted was perpendicular to the row. As the bicycle moved down the middle of the row, the shaft encoder logged NDVI readings each centimeter of linear distance travelled. By starting at the pre-determined point where each individual corn plant's distance was marked, it was then possible to calculate NDVI for each individual plant. This was done by calculating the average NDVI from readings that occurred halfway in front and halfway behind the individual corn plant (Freeman et al., 2007).

Individual plant corn grain yield was recorded by harvesting the ear(s) from each individual marked corn plant. The ears were dried in a forced air oven at $70^{\circ} \mathrm{C}$ for seven days. Corn ears were weighed then shelled, and the grain was weighed for each 
individual plant. In order to determine individual corn plant grain yield on an area basis, the distance halfway between the two bordering plants was calculated and multiplied by the row width $(0.76 \mathrm{~m})$. Final grain yield was adjusted to a standard moisture of $15.5 \%$, and then expressed as $\mathrm{kg} \mathrm{ha}^{-1}$.

Average stalk diameter was calculated by averaging the major and minor axis of the stalk. A value of average stalk diameter multiplied by height was created in an attempt to better characterize each corn plant, and to normalize the stalk diameter data. Date, growth stage, days after planting (DAP), and growing degree days (GDD) were recorded at the time each set of measurements were collected, as well as the specific plant populations, planting date, cultivars, and harvest dates for each location (Table 1). The monthly average air temperature and rainfall for each location and year of the experiments are summarized in Table 2. Summary statistics, including minimum, maximum, range, mean, standard deviation, and coefficient of variation, for the variables stalk diameter, plant height, and NDVI are summarized in Table 3, for growth stages V8, V10, V12, and VT, with sites and years combined. The major variables observed in this study were stalk diameter, stalk diameter X height, and NDVI (Table 4). All data from V8 to VT, at all locations, and across all years, were combined and analyzed. Data was analyzed by each growth stage individually, as well as being divided into 3 groups for analysis: V8-V10, V10-V12, and V12-VT. An effort was made to look at all groups with sites and years combined, in order to come up with a yield prediction equation that would work across sites and years. Simple correlation in SAS (SAS, 2003) was used to identify variables highly correlated with grain yield in this study. Using the variables stalk diameter, stalk diameter X height, and NDVI as independent variables, linear and non- 
linear regression analysis was performed, with by-plant corn grain yield $\left(\mathrm{kg} \mathrm{ha}^{-1}\right)$ as the dependent variable. For the Mexico data, non-linear regression analysis was performed, with stalk diameter as the independent variable and by-plant corn biomass $\left(\mathrm{kg} \mathrm{plant}^{-1}\right)$ as the dependent variable. The highest coefficient of determination $\left(r^{2}\right)$ was used to select the models with the best fit to the data. 


\section{CHAPTER IV}

\section{RESULTS AND DISCUSSION}

\section{NDVI X Plant Height Index}

Freeman et al. (2007) found that the index NDVI X plant height index exhibited strong relationships with by-plant $\mathrm{N}$ uptake, corn biomass, and corn forage yield. However, no previous studies have examined this relationship with by-plant corn grain yield. When examined for this study, NDVI X height showed $r^{2}$ values of $0.29,0.49$, 0.50, and 0.37, for growth stages V8, V10, V12, and VT, respectively (Table 5), for sites and years combined. When the growth stages were grouped together, the $r 2$ values were $0.13,0.39$, and 0.43 , for growth stage groups V8-V10, V10-V12, and V12-VT, respectively. Table 5 also compares the correlations of the NDVI X height index to other measurements taken in this experiment. While the NDVI X height index demonstrated strong $r^{2}$ values, other measurements, such as stalk diameter, height, and stalk diameter $\mathrm{X}$ height, provide even better relationships with final by-plant corn grain yield.

\section{Stalk Diameter}

Stalk diameter was significantly correlated with by-plant corn grain yield, especially at growth stages V10 to V12 (Fig. 1). When sites and years were combined at these growth stages, the relationship produced an $r^{2}$ value of 0.29 , and when sites and 
years were combined for growth stages V12 to VT, the resultant $r^{2}$ value was 0.16 (Fig. 2). However, when sites and years were combined for the earlier growth stages V8 to V10, the $r^{2}$ value was much lower at 0.06 (Fig. 3). This showed that stalk diameter had limited value in predicting grain yield by itself at early growth stages. This was supported by work from Shaw and Loomis (1950), which showed that stalk diameter was variable between varieties and years and not always correlated with yield. The best growth stages for using stalk diameter to predict yield were V10 to V12. All data were combined over sites and years, in order to produce a more robust model to be used over different environments and years. However, when examined by location and year, such as growth stage V12 at Lake Carl Blackwell, 2010, the relationship between stalk diameter and byplant grain yield were greatly improved, resulting in an $r^{2}$ value of 0.71 (Fig. 4). There was a wide range in the values for stalk diameter, which may have contributed to differences in sampling procedures between people, and whether or not the lowermost leaf was still attached to the stalk. In the later growth stages, the lowermost leaf began to senesce and fall off of the stalk. Depending on when this occurred, it may have affected the stalk diameter measurement, because this leaf sheath would have been attached to the first intermodal area where the stalk diameter measurements were taken. This is thought to have contributed to the lower relationships between stalk diameter and grain yield.

\section{Stalk Diameter X Plant Height}

Across years and locations, when stalk diameter was multiplied times plant height, the relationship between this index and by-plant corn grain yield was much improved. As seen in Figure 5, when stalk diameter X plant height was regressed against grain yield, the resultant $r^{2}$ value was 0.56 across sites and years for growth stages V10 to V12. Similar to stalk diameter 
only, the growth stages V10 to V12 exhibited the best relationship between stalk diameter X plant height and yield as compared to the other growth stages. At the Haskell location, at growth stage V10 only, an $r^{2}$ value of 0.55 for both years combined was recorded (Fig. 6). At growth stages V8 to V10, the $r^{2}$ value was much lower (0.15, Fig. 7), but when looking at growth stage V8, the $r^{2}$ value was 0.36 (Fig. 8). Using both plant height and stalk diameter increased correlation. This is consistent with the work from Freeman et al. (2007), where NDVI was multiplied with plant height to create a NDVI X plant height index and that proved to be a good predictor of by-plant forage yields. As is reported in Table 3, the $r^{2}$ values of stalk diameter X plant height was consistently greater than the correlation of stalk diameter by itself.

As the growth stage increased from V12 to VT, the $r^{2}$ values between stalk diameter X plant height and by-plant corn grain yield decreased when averaged over sites and years, resulting in a lower $r^{2}$ value of 0.49 (Fig. 9). When the data were evaluated separately, the relationship between stalk diameter X plant height and by-plant grain yield improved. For example, Lake Carl Blackwell in 2010 for growth stage V12 resulted in an $r^{2}$ of 0.67 (Fig. 10) for stalk diameter $\mathrm{X}$ plant height and grain yield. However, our purpose was to create a more robust equation that would work across sites and years. This index of stalk diameter X plant height was expected to improve prediction of by-plant corn grain yield potential, and that was found. This could then be used to refine midseason fertilizer $\mathrm{N}$ applications based on expected $\mathrm{N}$ removal by predicted yield. Nitrogen use efficiency can be increased using this method, as Raun et al. (2002) found when using projected differences in $\mathrm{N}$ uptake between $\mathrm{N}$ rich and farmer practice as the basis for prescribing midseason $\mathrm{N}$ rates. Normalizing the data using the INSEY method (Raun et al., 2002) produced only slightly better correlation than the previous methods described. For this INSEY method, the value of stalk diameter X plant height was divided by the cumulative growing degree days (GDD), and then correlated to by-plant corn grain yield. Normalizing stalk 
diameter X height measurements using GDD data (over growth stages) did not assist in improving the prediction of by-plant corn grain yield (data not reported).

\section{Biomass}

Another location in Mexico was examined to evaluate the relationship of stalk diameter and by-plant corn biomass. Stalk circumference was measured at growth stage V15, and was then converted to stalk diameter. Stalk diameter was highly correlated with plant biomass, exhibiting a polynomial relationship and an $r^{2}$ value of 0.68 (Fig. 11). Area was not figured into the biomass measurements, because prior research by Freeman et al. (2007) suggests that area occupied by each plant was not related to dry biomass per plant. This suggests that stalk diameter measurements can not only help predict by-plant grain yield, but biomass as well, without using NDVI as a predictor variable.

\section{Yield by Distance and NDVI}

Figures 12 and 13 show stalk diameter X plant height and NDVI as compared to the byplant corn grain yield by distance down one row of corn. Figure 12 shows this data for Lake Carl Blackwell at growth stage V8, and Figure 13 shows this data for Haskell at V10. One thing to note about these figures is how stalk diameter $\mathrm{X}$ plant height shows more variability down the row, and how closely it corresponds to the by-plant corn grain yield. However, when looking at the corresponding NDVI measurements for the plants down the row, the NDVI values are less variable. When examining the CV (coefficient of variation) for Figures 12 and 13, it can be seen that the $\mathrm{CV}$ is higher for the stalk diameter $\mathrm{X}$ height measurement than the NDVI measurement in both instances, indicating more variability in the values of stalk diameter X height. At growth stage V8, the CV is $10.7 \%$ for stalk diameter $\mathrm{X}$ height, as compared to only $7.6 \%$ for NDVI (Fig. 12). At the later growth stages, such as at V10 in Figure 13, the difference in CV's are more easily seen, with a CV of $17.2 \%$ for stalk diameter $\mathrm{X}$ height and 5.6\% CV for NDVI. This 
suggests that stalk diameter X plant height can be a more accurate indicator of individual corn plant yield than NDVI. This is probably due to the overlapping of corn leaves across plants, therefore averaging out differences between plants when using NDVI. A good example of this is one corn plant at approximately $125 \mathrm{~cm}$ in Figure 13, which had no measurable yield. The stalk diameter X plant height measurement was able to capture the difference in yield, but NDVI did not. Again, this is likely due to the overlapping of leaves from the two larger neighboring corn plants, which kept that corn plant from being able to be "seen" by the GreenSeeker sensor.

Additionally, when considering the relationship between NDVI and by-plant corn grain yield, the correlation $\left(r^{2}\right)$ increased from 0.04 at V8, to 0.26 at V10, to 0.32 at V12, and then decreased at tasselling to 0.15 (Table 3). Alternatively, the $r^{2}$ values for stalk diameter X plant height for the same growth stages were $0.36,0.55,0.67$, and 0.10 , respectively. This further suggests that NDVI may not be the best variable for predicting by-plant corn yield. 


\section{CHAPTER V}

\section{CONCLUSIONS}

The objective of this experiment was to determine if stalk diameter and plant height measurements could accurately predict final corn grain yield on a by-plant basis at different stages of corn development. The results from this experiment show that byplant corn grain yields can be predicted using mid-season stalk diameter and plant height measurements. Stalk diameter measurements can also be used to predict in-season byplant biomass. Multiplying stalk diameter times plant height gave the best prediction of by-plant grain yield on an area basis from growth stages V8 to V12.

The data collected from this experiment validate the need to use other physiological traits besides just NDVI in determining yield potential, and that will ultimately be used to make midseason fertilizer $\mathrm{N}$ recommendations. In addition, this data will be used to help refine the current yield prediction equations that are used for determining mid-season $\mathrm{N}$ rates. This work could also be used to substantiate the need for on-the-go by-plant monitoring and application of topdress $\mathrm{N}$ to individual corn plants. Further data collection will be needed for several more years and over more locations to help refine the data for more precise yield prediction using the stalk diameter $\mathrm{X}$ height method. Also, further studies on the effects of nitrogen rate and environment will be 
needed to determine the effect that these factors have on the potential for yield prediction using the stalk diameter $\mathrm{X}$ height measurement. Future studies using the stalk diameter $\mathrm{X}$ height measurement will also look at how to implement this strategy for $\mathrm{N}$ management within a corn field. A possible solution will be to compare stalk diameter X height measurements from the majority of a field to the measurements within an N-rich strip. This N-rich strip will determine the maximum yield potential for the field, and will then help determine the response index for which $\mathrm{N}$ recommendations will be derived from. The need for more precisely placed $\mathrm{N}$ fertilizer, even down to the by-plant level, can be more easily achieved using methods such as stalk diameter X plant height indices for midseason $\mathrm{N}$ applications. 


\section{REFERENCES}

Freeman, K. W., K. Girma, D. B. Arnall, R. W. Mullen, K. L. Martin, R. K. Teal, and W. R. Raun. 2007. By-plant prediction of corn forage biomass and nitrogen uptake at various growth stages using remote sensing and plant height. Agron. J. 99:530536.

Hager, Aaron. 21 May 2010. Corn growth stages and postemergence herbicides. The Bulletin, Issue no. 7. Available at http://bulletin.ipm.illinois.edu/article.php?id=1317 [verified 10 Feb 2011]. University of Illinois Extension, Urbana - Champaign, IL.

Jones, R. M., M. A. Sanderson, J. C. Read, and A. C. Lovell. 1995. Management of corn for silage production in South Central USA. J. Prod. Agric. 8:175-180.

Malakoff, D. 1998. Death by suffocation in the Gulf of Mexico. Science (Washington, D.C.) 281:190-192.

Martin, K. L., K. Girma, K. W. Freeman, R. K. Teal, B. Tubana, D. B. Arnall, B. Chung, O. Walsh, J. B. Solie, M. L. Stone, and W. R. Raun. 2007. Expression of variability in corn as influenced by growth stage using optical sensor measurements. Agron. J. 99:384-389. 
Martin, K. L., P. J. Hodgen, K. W. Freeman, R. Melchiori, D. B. Arnall, R. K. Teal, R. W. Mullen, K. Desta, S. B. Phillips, J. B. Solie, M. L. Stone, O. Caviglia, F. Solari, A. Bianchini, D. D. Francis, J. S. Schepers, J. L. Hatfield, and W. R. Raun. 2005. Plant-to-plant variability in corn production. Agron. J. 97:1603-1611. Nitrogen Use Efficiency website. Resolution for Precision Agriculture. Accessed at http://nue.okstate.edu/Index_Resolution.htm (October 15, 2010).

Pordesimo, L. O., W. C. Edens, and S. Sokhansanj. 2004. Distribution of aboveground biomass in corn stover. Biomass and Bioenergy 26:337-343.

Raun, Bill. 2010. At what resolution should precision agriculture operate? [Online.] [9 p.] Available at www.nue.okstate.edu/Index_Resolution.htm (accessed 15 October 2010; verified 16 October 2010) Oklahoma State Univ., Stillwater, OK.

Raun, W. R., and G. V. Johnson. 1999. Improving nitrogen use efficiency for cereal production. Agron. J. 91:357-363.

Raun, W. R., Gordon V. Johnson, Jeffory A. Hattey, Shannon L. Taylor and Heather L. Lees. 1997. Nitrogen cycle ninja, a teaching exercise. J. Nat. Resour. Life Sci. Educ. 26:39-42.

Raun, W. R., J. B. Solie, G. V. Johnson, M. L. Stone, R. W. Mullen, K. W. Freeman, W. E. Thomason, and E. V. Lukina. 2002. Improving nitrogen use efficiency in cereal grain production with optical sensing and variable rate application. Agron. J. 94:815-820.

Raun, W. R., J. B. Solie, K. L. Martin, K. W. Freeman, M. L. Stone, G. V. Johnson, and R. W. Mullen. 2005. Growth stage, development, and spatial variability in corn evaluated using optical sensor readings. J. Plant Nutr. 28:173-182. 
Raun, W. R., J. B. Solie, G. V. Johnson, M. L. Stone, R. W. Whitney, H. L. Lees, H. Sembiring, and S. B. Phillips. 1998. Micro-variability in soil test, plant nutrient, and yield parameters in bermudagrass. Soil Sci. Soc. Am. J. 62:683-690.

Ritchie, S. W., J.J. Hanway, and G. O. Benson. 1996. How a corn plant develops. Iowa State Univ., Coop. Ext. Serv., SR-48, Ames, IA.

SAS Institute. 2003. The SAS system for windows version 9.2. SAS Inst., Cary, NC.

Searcy, S. W and C. Stephens. 1997. Precision farming: a new approach to crop management. Texas Agricultural Extension Service publication. L-5177. Available at http://lubbock.tamu.edu/soilfertility/pdfs/PrecisionFarmNew.pdf [verified 10 Feb 2011].

Shaw, R. H., and W. E. Loomis. 1950. Bases for the prediction of corn yields. Plant Physiol. 25(2):225-244.

Sorenson, R. B., M. C. Lamb, and C. L. Butts. 2006. Row pattern, plant density, and nitrogen rate effects on corn yield in the Southeastern US. Crop Management, Plant Management Network. Available at http://ddr.nal.usda.gov/dspace/bitstream/10113/11930/1/IND43898481.pdf [verified 16 Oct 2010].

Solie, J.B., W. R. Raun, R. W. Whitney, M.L. Stone, and J.D. Ringer. 1996. Optical sensor based field element size and sensing strategy for nitrogen application. Trans. ASAE 39(6):1983-1992.

Solie, J. B., W. R. Raun, and M. L. Stone. 1999. Submeter spatial variability of selected soil and plant variables. Soil Sci. Soc. Am. J. 63:1724-1733. 
Teal, R. K., W. R. Raun, J. B. Solie, M. L. Stone, K. W. Freeman, G. V. Johnson, and K. L. Martin. 2004. By-plant precision sensing for variable nitrogen rate application in corn. Precision Agriculture Conference, St. Paul, Minnesota, July 2004. Available at http://nue.okstate.edu/Index_Publications.htm [verified 15 Oct 2010]. 


\section{TABLES}

Table 1. Planting and harvest dates, growth stages, days after planting, (DAP), growing degree days (GDD), and plant population of corn rows used for stalk diameter, height, and sensor measurements at Lake Carl Blackwell (LCB, irrigated), Haskell, Efaw, OK, and Ciudad Obregón, Mexico, 2009-2011.

\begin{tabular}{|c|c|c|c|c|c|c|c|}
\hline & & & & & Sensin & Times & \\
\hline & Planted & Population & Harvest & Date & Stage $\dagger$ & DAP & GDD \\
\hline & & Plants ha ${ }^{-1}$ & & & & & \\
\hline 2009 & & & & & & & \\
\hline Haskell $^{1}$ & 28 May & 61775 & 21 October & & & & \\
\hline $1 .+$ & & & & 7 July & V8 & 41 & 1113.8 \\
\hline 2. & & & & 16 July & V10 & 50 & 1432.6 \\
\hline 3. & & & & 27 July & VT & 61 & 1726.8 \\
\hline 2009 & & & & & & & \\
\hline $\mathrm{LCB}^{2}$ & 19 May & 83643 & 28 September & & & & \\
\hline 1. & & & & 1 July & V8 & 44 & 1150.9 \\
\hline 2. & & & & 15 July & VT & 58 & 1628.9 \\
\hline 2010 & & & & & & & \\
\hline Haskell ${ }^{1}$ & 4 May & 61775 & 17 August & & & & \\
\hline 1. & & & & 25 June & V10 & 53 & 1300.8 \\
\hline 2010 & & & & & & & \\
\hline $\mathrm{LCB}^{1}$ & 25 May & 86485 & 16 September & & & & \\
\hline 1. & & & & 28 June & V8 & 35 & 1033.3 \\
\hline 2. & & & & 7 July & V12 & 44 & 1287.0 \\
\hline 2010 & & & & & & & \\
\hline Efaw $^{1}$ & 28 April & 49667 & 24 August & & & & \\
\hline 1. & & & & 17 June & V8 & 51 & 1083.4 \\
\hline 2011 & & & & & & & \\
\hline Mexico $^{3}$ & 14 Oct'10 & 67700 & 14 Feb '11 & & & & \\
\hline 1. & & & & 10 Jan' & V15 & 89 & NA \\
\hline${ }^{1}$ Variety pla & ed: DeKall & DKC 52-59 & & & & & \\
\hline${ }^{2}$ Variety pla & ed: DeKall & DKC 67-23 & & & & & \\
\hline${ }^{3}$ Variety pl & ed: Cebu & & & & & & \\
\hline $\begin{array}{l}\dagger \text { Corn grov } \\
\text { visible. VT } \\
+\quad \text { Number o }\end{array}$ & $\begin{array}{l}\text { stages V8, } \\
\text { fined as the } \\
\text { talk diamet }\end{array}$ & $\begin{array}{l}\mathrm{V} 10 \text {, and V1 } \\
\text { last branch o } \\
\text { ar height anc }\end{array}$ & $\begin{array}{l}2 \text { defined as the } \\
\text { f tassel being co } \\
\text { d sensor measure }\end{array}$ & $\begin{array}{l}\text { the and } 1 \\
\text { ely visibl } \\
\text { for each }\end{array}$ & $\begin{array}{l}\text { leaves } \\
\text { (Ritchie } \\
\text { ite-vear }\end{array}$ & $\begin{array}{l}\text { h colla } \\
\text { al., } 19\end{array}$ & $\begin{array}{l}\text { rs } \\
96) .\end{array}$ \\
\hline
\end{tabular}


Table 2. Average total rainfall and temperature during corn growing months at Lake Carl Blackwell, Efaw, and Haskell, 2009 and 2010.

\begin{tabular}{|c|c|c|c|c|c|c|}
\hline \multirow[b]{2}{*}{ Month } & \multicolumn{3}{|c|}{ Rainfall } & \multicolumn{3}{|c|}{ Avg. air temperature } \\
\hline & 2009 & 2010 & Average & 2009 & 2010 & Average \\
\hline & \multicolumn{3}{|c|}{ 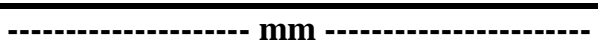 } & \multicolumn{3}{|c|}{ 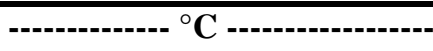 } \\
\hline \multicolumn{7}{|c|}{ 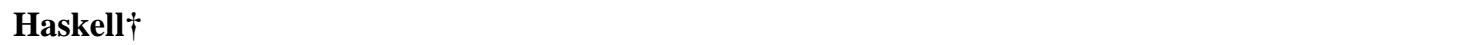 } \\
\hline April & 121.2 & 45.7 & 151.1 & 14.5 & 16.7 & 15.4 \\
\hline May & 113.0 & 150.4 & 176.8 & 18.9 & 20.5 & 20.5 \\
\hline June & 60.7 & 100.8 & 154.9 & 25.8 & 26.7 & 24.4 \\
\hline July & 45.2 & 115.1 & 123.4 & 26.0 & 27.4 & 27.2 \\
\hline August & 21.8 & 29.7 & 104.6 & 25.1 & 28.3 & 27.1 \\
\hline September & 187.2 & 149.9 & 131.6 & 20.6 & 22.7 & 22.4 \\
\hline \multicolumn{7}{|c|}{ Lake Carl Blackwell $\ddagger$} \\
\hline April & 119.9 & 108.5 & 121.4 & 14.6 & 16.8 & 15.1 \\
\hline May & 77.0 & 156.2 & 112.3 & 18.7 & 19.5 & 20.4 \\
\hline June & 52.3 & 176.8 & 141.2 & 26.6 & 26.7 & 24.4 \\
\hline July & 131.6 & 55.1 & 105.9 & 26.5 & 27.7 & 27.7 \\
\hline August & 183.4 & 67.1 & 93.2 & 24.8 & 28.0 & 27.3 \\
\hline September & 113.0 & 80.5 & 104.1 & 20.4 & 23.0 & 22.2 \\
\hline \multicolumn{7}{|l|}{ Efaw +} \\
\hline April & $--^{\wedge}$ & 91.7 & 121.4 & $--^{\wedge}$ & 17.1 & 15.1 \\
\hline May & -- & 181.1 & 112.3 & -- & 19.9 & 20.4 \\
\hline June & -- & 139.4 & 141.2 & -- & 26.9 & 24.4 \\
\hline July & -- & 111.5 & 105.9 & -- & 27.7 & 27.7 \\
\hline August & -- & 63.8 & 93.2 & -- & 28.2 & 27.3 \\
\hline September & -- & 70.6 & 104.1 & -- & 23.3 & 22.2 \\
\hline
\end{tabular}

$\dagger$ Monthly averages from Haskell Mesonet@ station, $1994-2004$.

¥ Monthly averages for Efaw and Lake Carl Blackwell are from Stillwater Mesonet@ station, 1994 - 2004.

${ }^{\wedge}$ No trial data was taken from Efaw in 2009. 
Table 3. Summary statistics for plant height, stalk diameter, and NDVI measurements at growth stages V8, V10, V12, and VT, averaged over sites and years.

\begin{tabular}{|c|c|c|c|c|c|c|c|}
\hline Growth Stage & Variable & Min & Max & Range & Mean & Std Dev & $\mathrm{CV}$ \\
\hline \multirow[t]{3}{*}{$\mathrm{V8}$} & Stalk diameter & 1.03 & 2.64 & 1.61 & 2.00 & 0.27 & 13.7 \\
\hline & Height & 45 & 157 & 112 & 92.2 & 21.7 & 23.6 \\
\hline & NDVI & 0.143 & 0.872 & 0.729 & 0.622 & 0.152 & 24.4 \\
\hline \multirow[t]{3}{*}{ V10 } & Stalk diameter & 1.22 & 2.76 & 1.54 & 2.24 & 0.22 & 9.8 \\
\hline & Height & 92 & 195 & 103 & 134 & 25.2 & 18.8 \\
\hline & NDVI & 0.442 & 0.838 & 0.396 & 0.704 & 0.091 & 12.9 \\
\hline \multirow[t]{3}{*}{ V12 } & Stalk diameter & 1.30 & 2.89 & 1.59 & 2.07 & 0.26 & 12.4 \\
\hline & Height & 85 & 170 & 85 & 128.5 & 20.7 & 16.1 \\
\hline & NDVI & 0.324 & 0.724 & 0.400 & 0.571 & 0.091 & 16.0 \\
\hline \multirow[t]{3}{*}{ VT } & Stalk diameter & 1.36 & 2.65 & 1.29 & 2.05 & 0.24 & 11.6 \\
\hline & Height & 100 & 216 & 116 & 149.6 & 27.9 & 18.7 \\
\hline & NDVI & 0.252 & 0.791 & 0.539 & 0.586 & 0.111 & 18.9 \\
\hline
\end{tabular}


Table 4. Linear relationship between by plant grain yield and measured plant height, stalk diameter, and NDVI, at V8, V10, V12, and VT corn growth stages, averaged across locations and years in Oklahoma, and polynomial relationship between by plant biomass and stalk diameter in Mexico, V15, 2011.

Variable

\begin{tabular}{|c|c|c|c|}
\hline Growth stage of corn & Independent & Dependent & $r^{2}+$ \\
\hline V8 & Height & Grain yield, $\mathrm{kg} \mathrm{ha}^{-1}$ & $0.35 * *$ \\
\hline V8 & Stalk diameter & & $0.11 * *$ \\
\hline V8 & Stalk diameter*height & & $0.36 * *$ \\
\hline V8 & NDVI & & $0.04 * *$ \\
\hline V10 & Height & Grain yield, $\mathrm{kg} \mathrm{ha}^{-1}$ & $0.52 * *$ \\
\hline V10 & Stalk diameter & & $0.10 * *$ \\
\hline V10 & Stalk diameter*height & & $0.55 * *$ \\
\hline V10 & NDVI & & $0.26 * *$ \\
\hline V12 & Height & Grain yield, $\mathrm{kg} \mathrm{ha}^{-1}$ & $0.53 * *$ \\
\hline V12 & Stalk diameter & & $0.71 * *$ \\
\hline V12 & Stalk diameter*height & & $0.67 * *$ \\
\hline V12 & NDVI & & $0.32 * *$ \\
\hline VT & Height & Grain yield, $\mathrm{kg} \mathrm{ha}^{-1}$ & $0.51 * *$ \\
\hline VT & Stalk diameter & & $0.03 *$ \\
\hline VT & Stalk diameter*height & & $0.10 * *$ \\
\hline VT & NDVI & & $0.15 * *$ \\
\hline V15 & Stalk diameter & Biomass, kg plant ${ }^{-1}$ & $0.68 * * \wedge$ \\
\hline
\end{tabular}

* Model significant at the 0.05 level of probability.

** Model significant at the 0.01 level of probability.

$\$ r^{2}$ denotes the proportion of variability in the dependent variable explained by the independent variable by the selected model.

II ns, not significant.

$\wedge$ Relationship was a $2^{\text {nd }}$ order polynomial.

V8 - eight fully collared leaves.

V10 - ten fully collared leaves.

V12 - twelve fully collared leaves.

V15 - fifteen fully collared leaves.

VT - corn tasseling. 
Table 5. Relationship of NDVI X plant height, plant height, stalk diameter, stalk diameter $\mathrm{X}$ height, and NDVI to by-plant corn grain yield, for growth stages V8, V10, V12, VT, and growth stage groups V8-V10, V10-V12, and V12-VT, averaged over sites and years.

\begin{tabular}{llllll}
\hline Growth Stages & NDVI X HT & HT & SD & SD X HT & NDVI \\
\cline { 2 - 5 } & & & & \\
\hline V8 & 0.29 & 0.35 & 0.11 & 0.36 & 0.04 \\
V10 & 0.49 & 0.52 & 0.10 & 0.55 & 0.26 \\
V12 & 0.50 & 0.53 & 0.71 & 0.67 & 0.33 \\
VT & 0.37 & 0.52 & 0.03 & 0.40 & 0.15 \\
& & & & & \\
V8-V10 & 0.13 & 0.15 & 0.06 & 0.15 & 0.04 \\
V10-V12 & 0.39 & 0.50 & 0.29 & 0.56 & 0.17 \\
V12-VT & 0.43 & 0.53 & 0.16 & 0.49 & 0.20 \\
\hline
\end{tabular}

NDVI = normalized difference vegetation index; HT = plant height; SD = stalk diameter. 


\section{FIGURES}

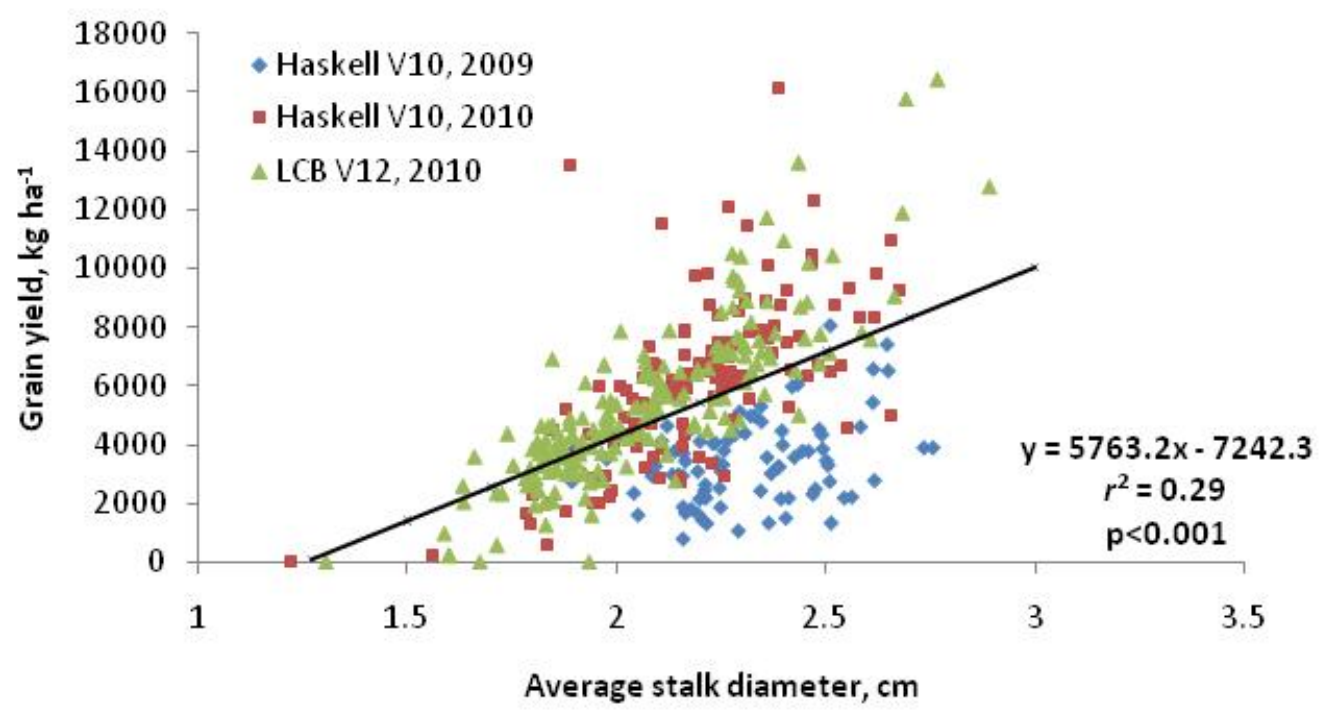

Fig. 1. Relationship between stalk diameter and by-plant corn grain yield for growth stages V10-V12, Haskell and Lake Carl Blackwell, 2009-2010. 


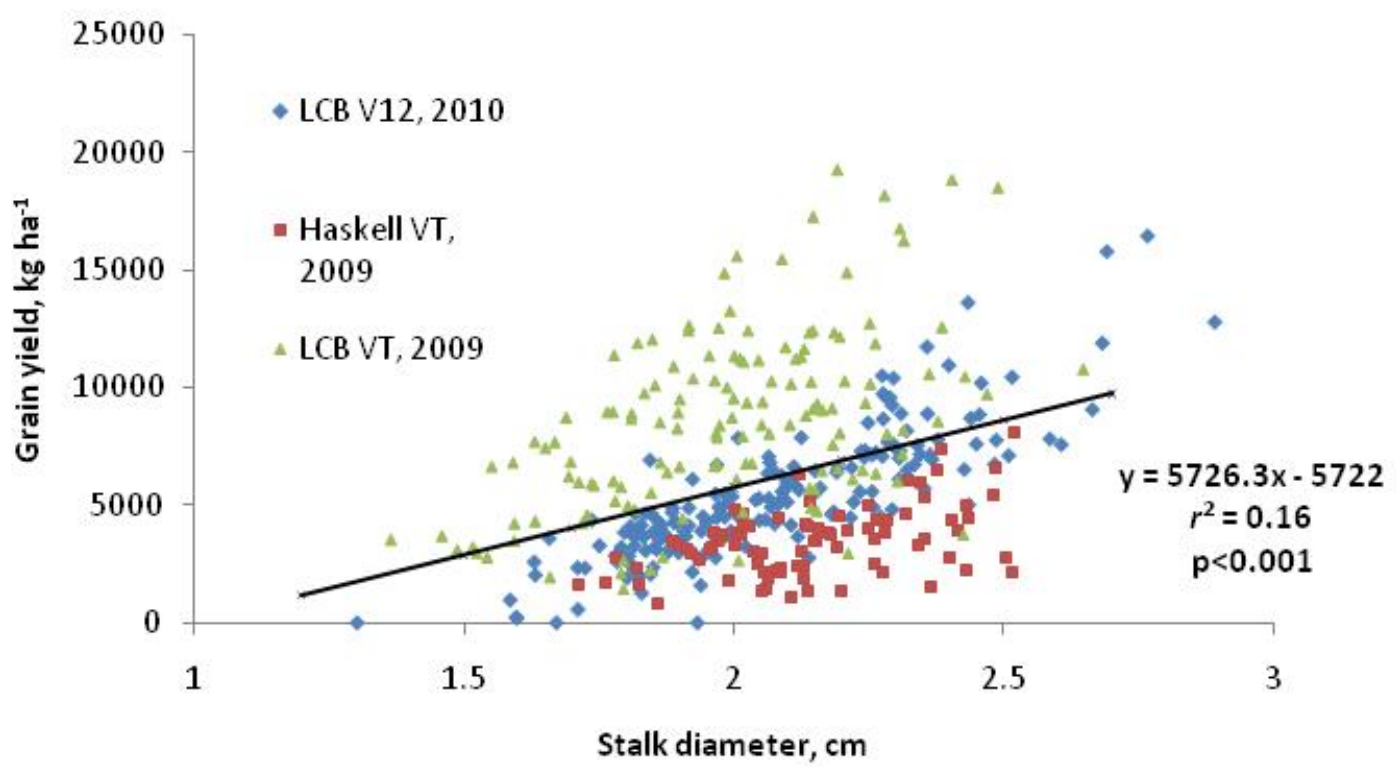

Fig. 2. Relationship between stalk diameter and by-plant corn grain yield, growth stages V12-VT, Haskell and Lake Carl Blackwell, 2009 - 2010. 


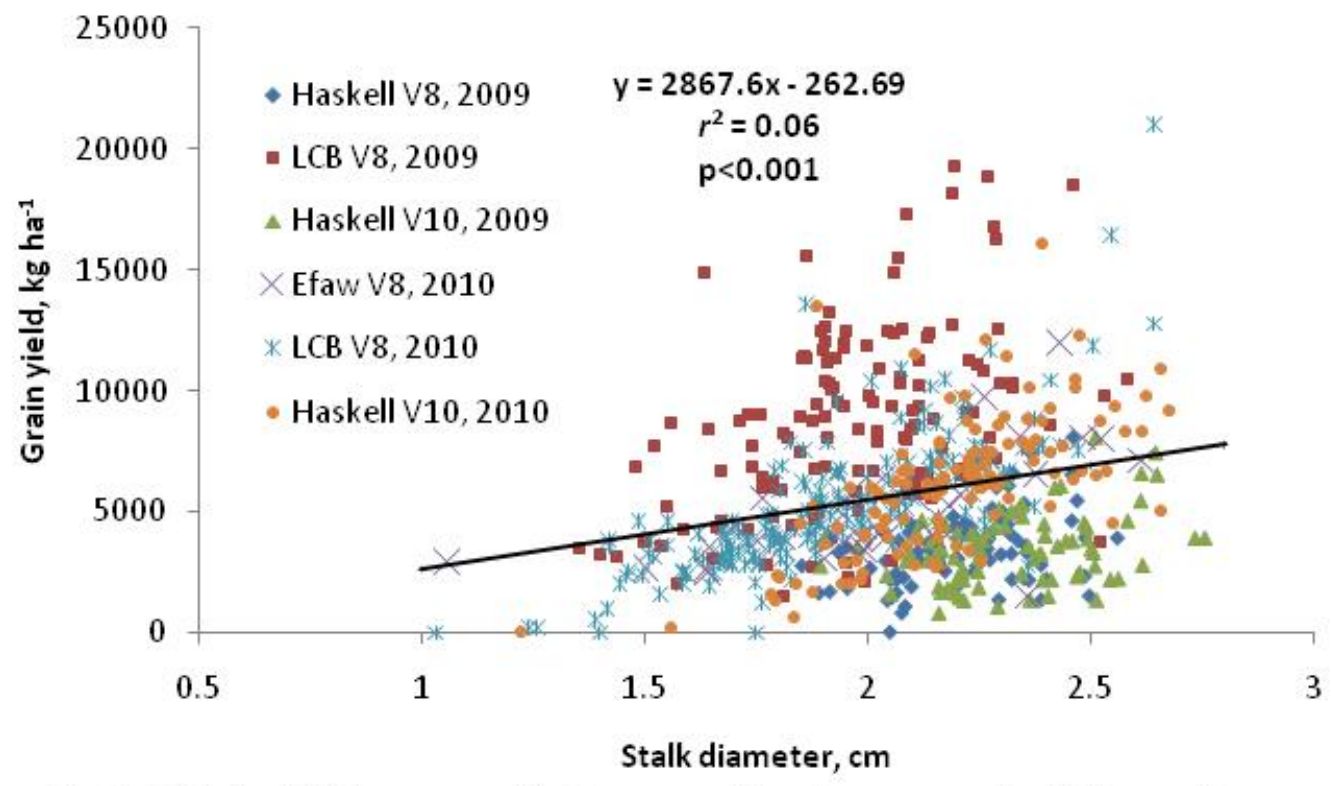

Fig. 3. Relationship between stalk diameter and by-plant corn grain yield, growth stages V8 to V10, Haskell, Lake Carl Blackwell, and Efaw, 2009 and 2010. 


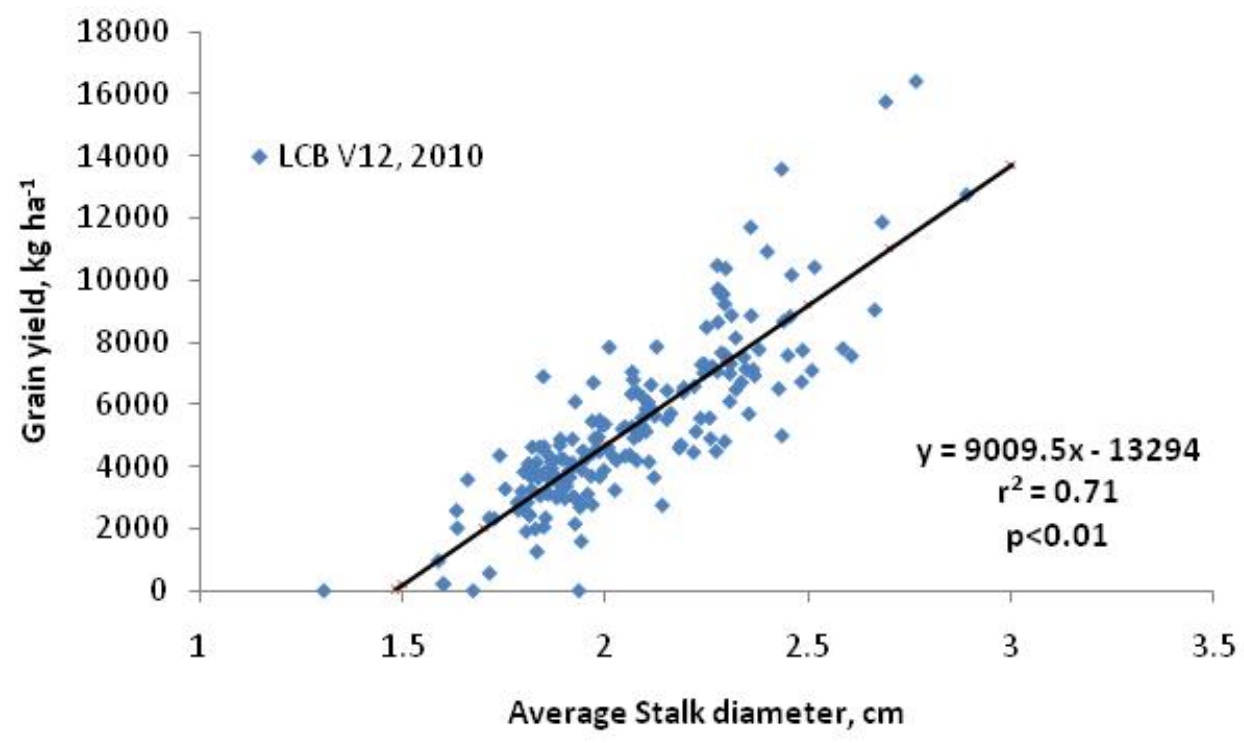

Fig. 4. Relationship between stalk diameter and by-plant corn grain yield at growth stage V12, Lake Carl Blackwell, 2010. 


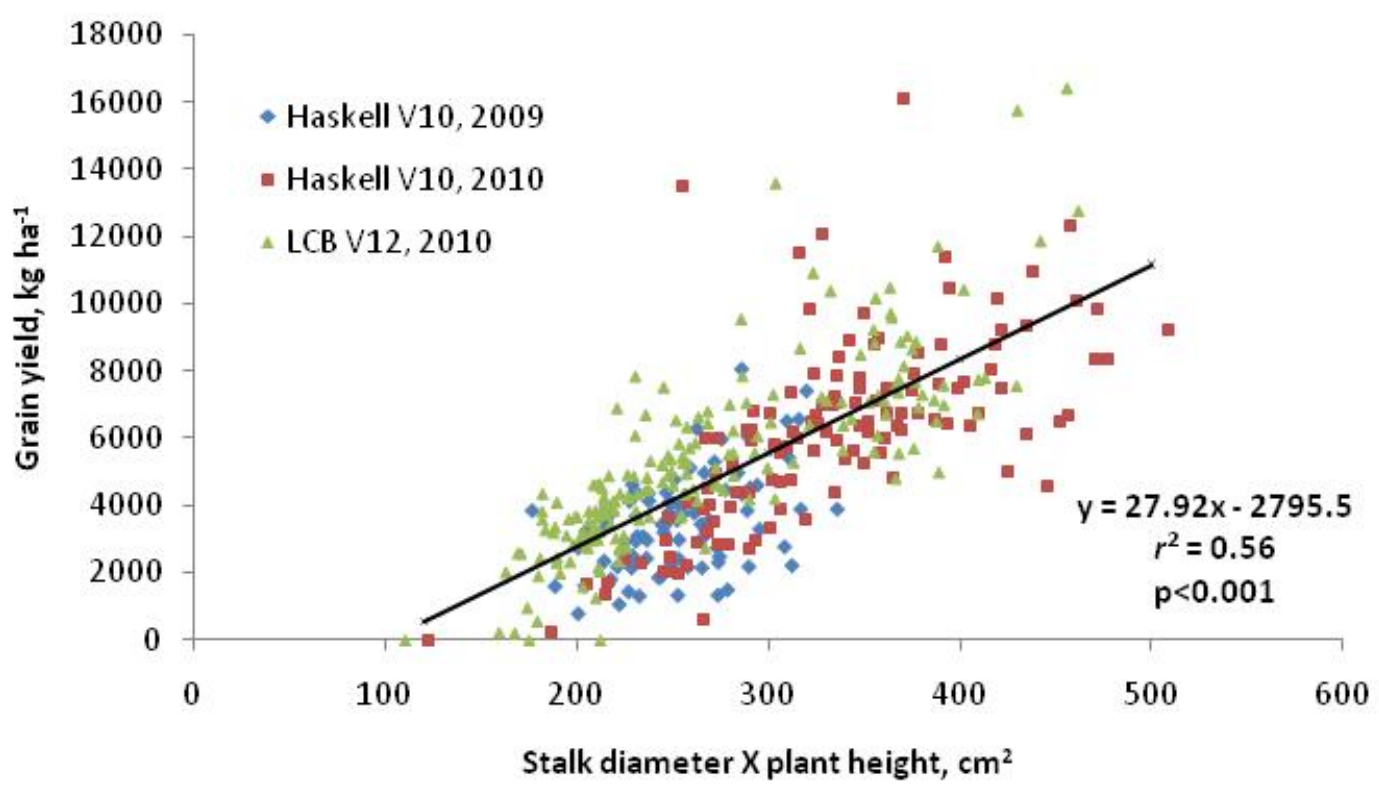

Fig. 5. Relationship between stalk diameter $X$ plant height and by-plant corn grain yield, growth stages V10 to V12, Haskell and Lake Carl Blackwell, 2009 and 2010. 


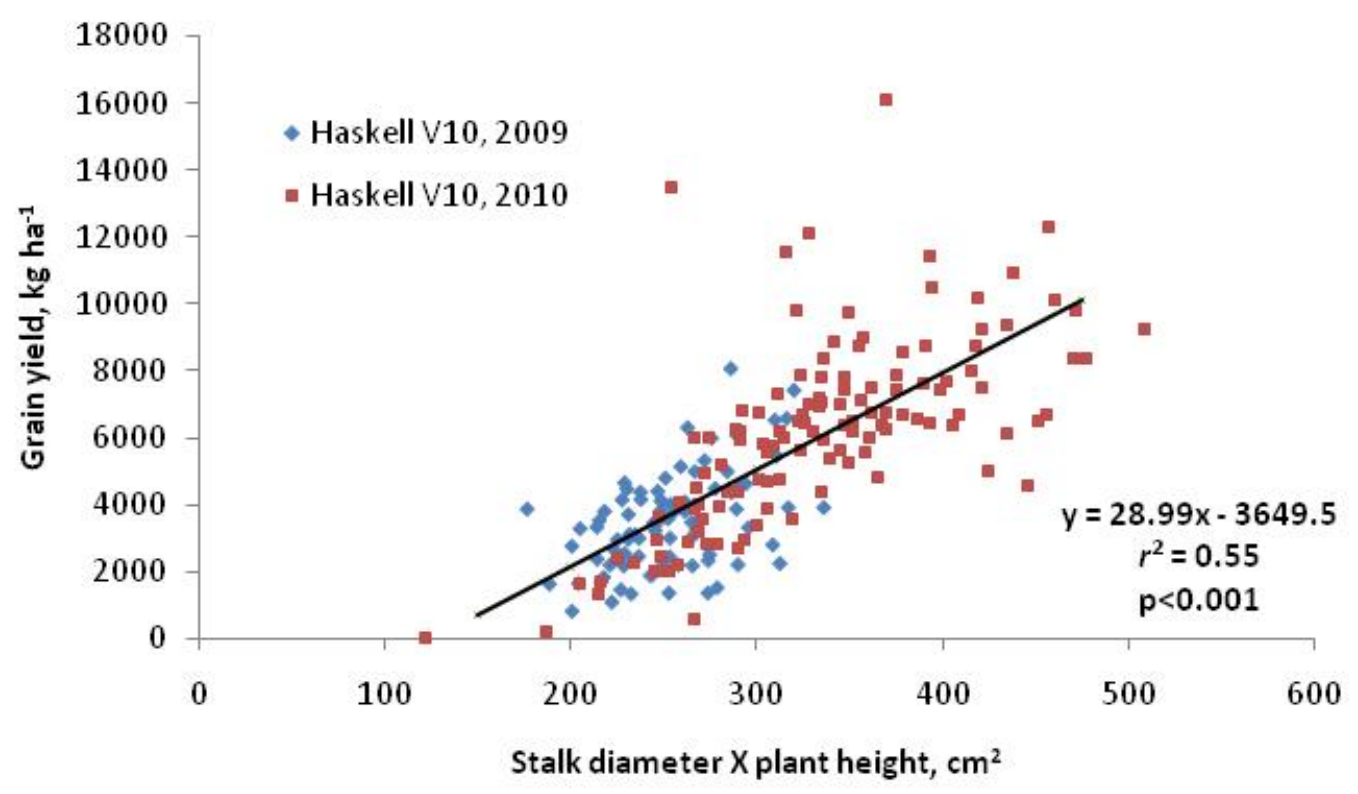

Fig. 6. Relationship between stalk diameter $X$ plant height and by-plant corn grain yield, growth stage V10, Haskell, 2009-2010. 


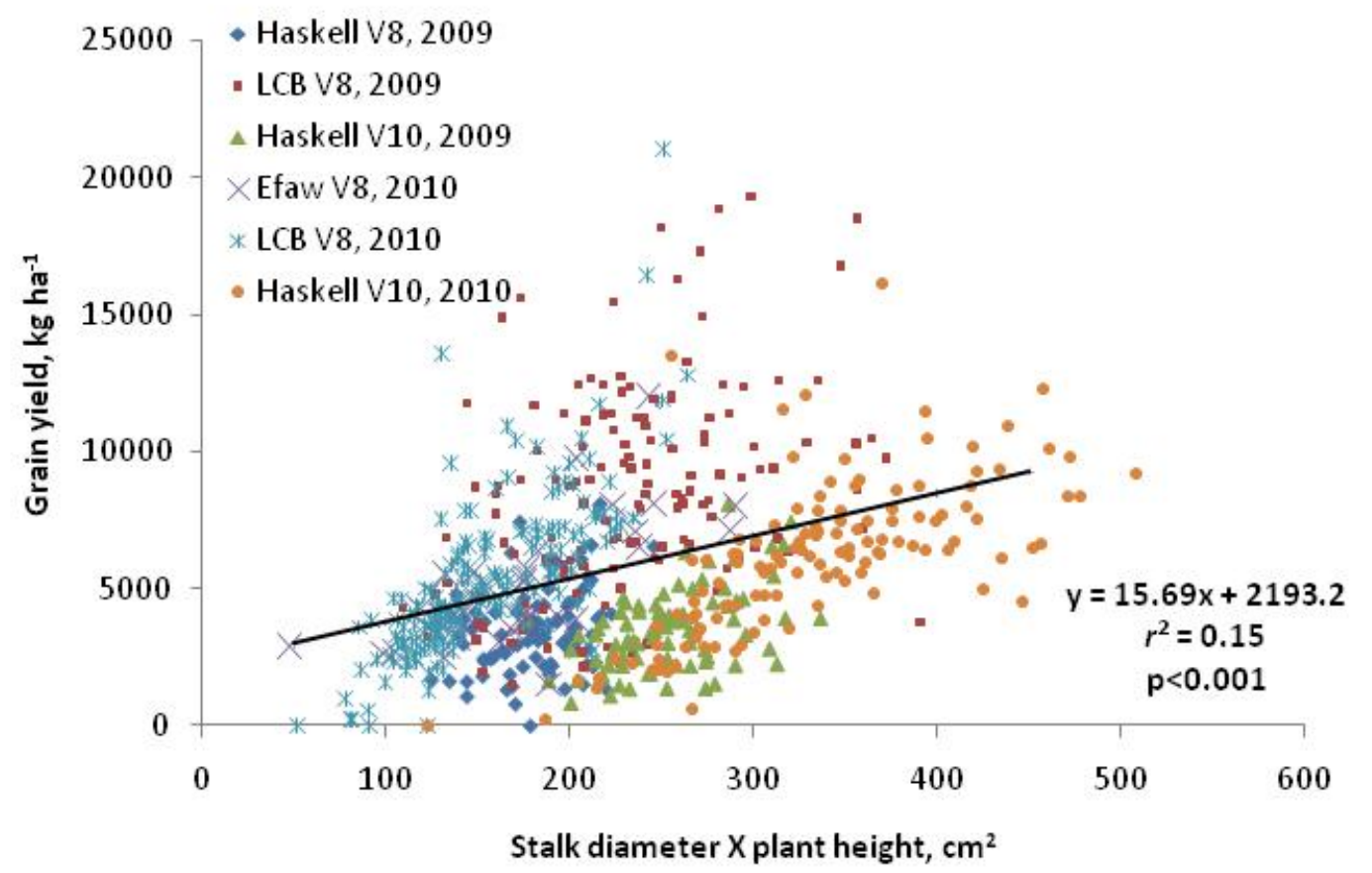

Fig. 7. Relationship between stalk diameter X plant height and by-plant corn grain yield, growth stages V8 to V10, Efaw, Lake Carl Blackwell, and Haskell, 2009 and 2010. 


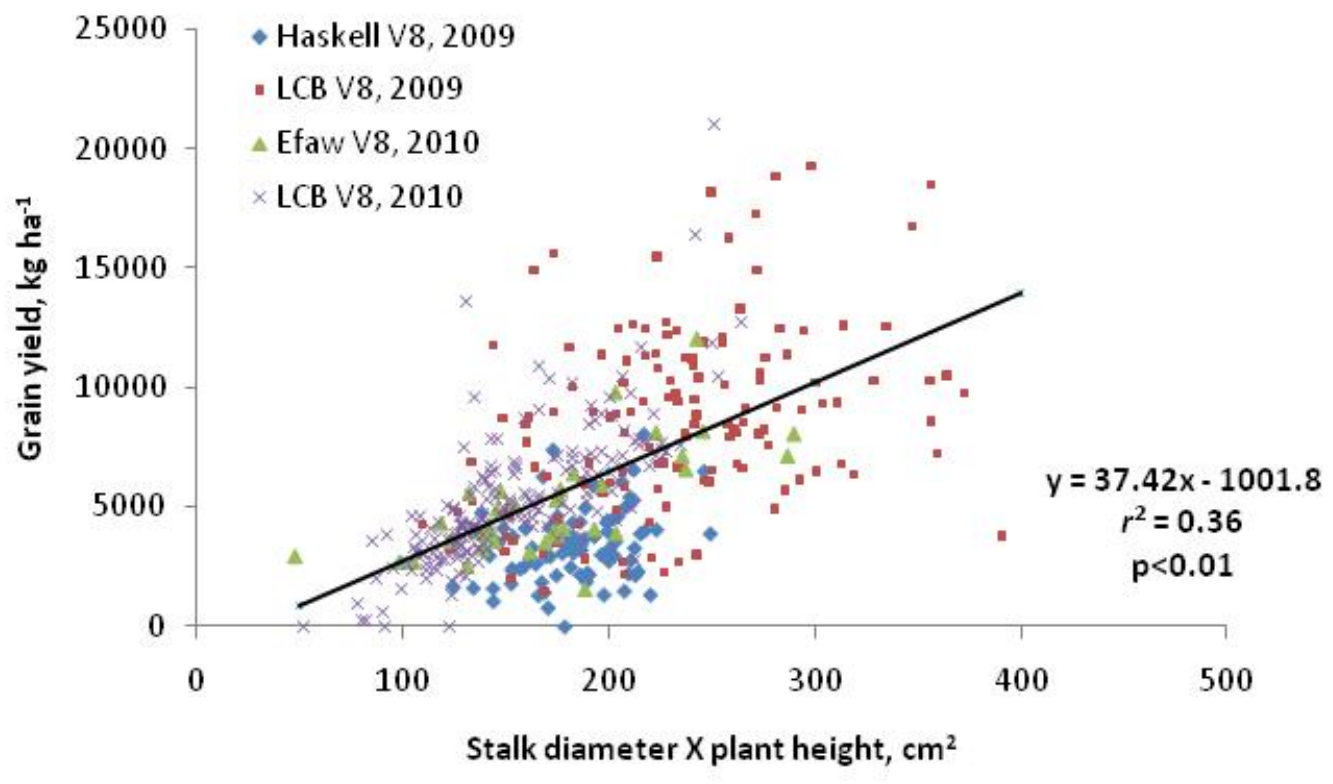

Fig. 8. Relationship between stalk diameter $X$ plant height and by-plant corn grain yield, growth stage V8, Haskell, Lake Carl Blackwell, and Efaw, 2009 and 2010. 


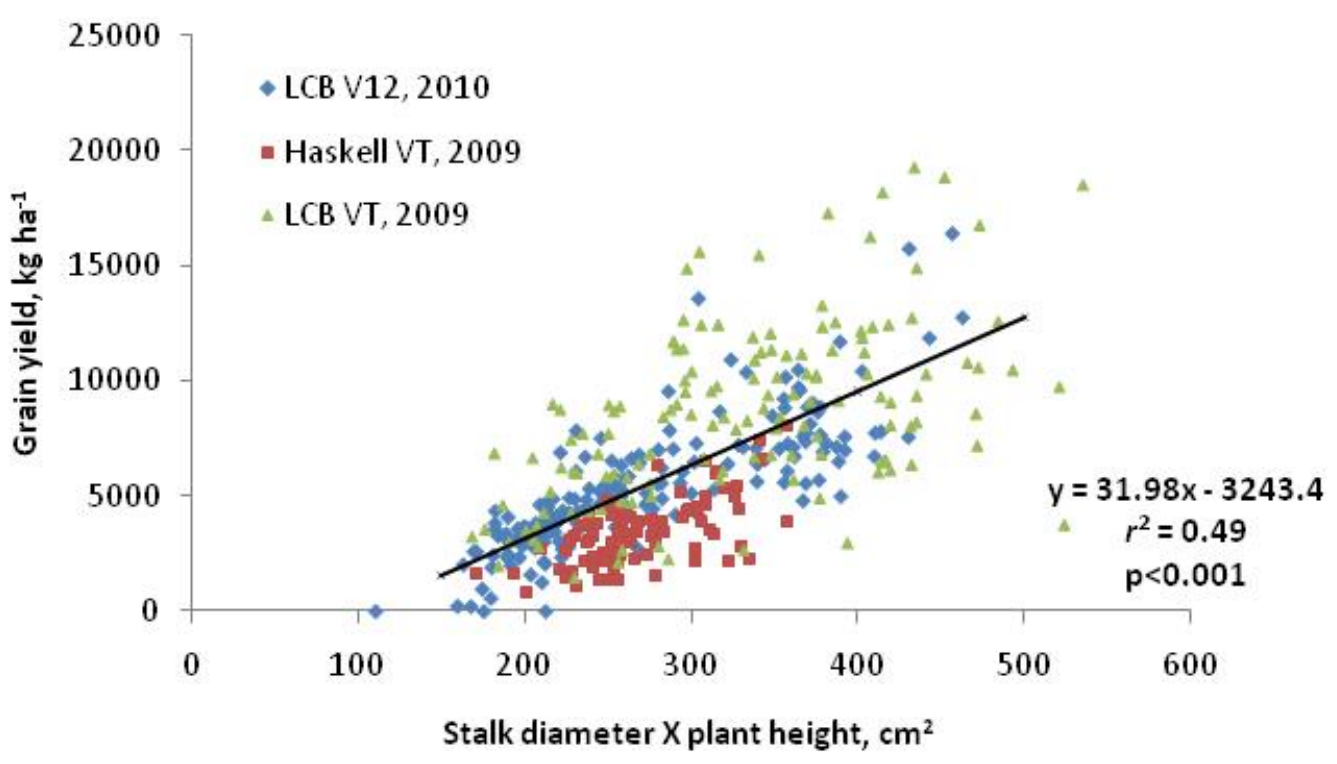

Fig. 9. Relationship between stalk diameter $X$ plant height and by-plant corn grain yield, growth stages V12 to VT, Haskell and Lake Carl Blackwell, 2009 and 2010. 


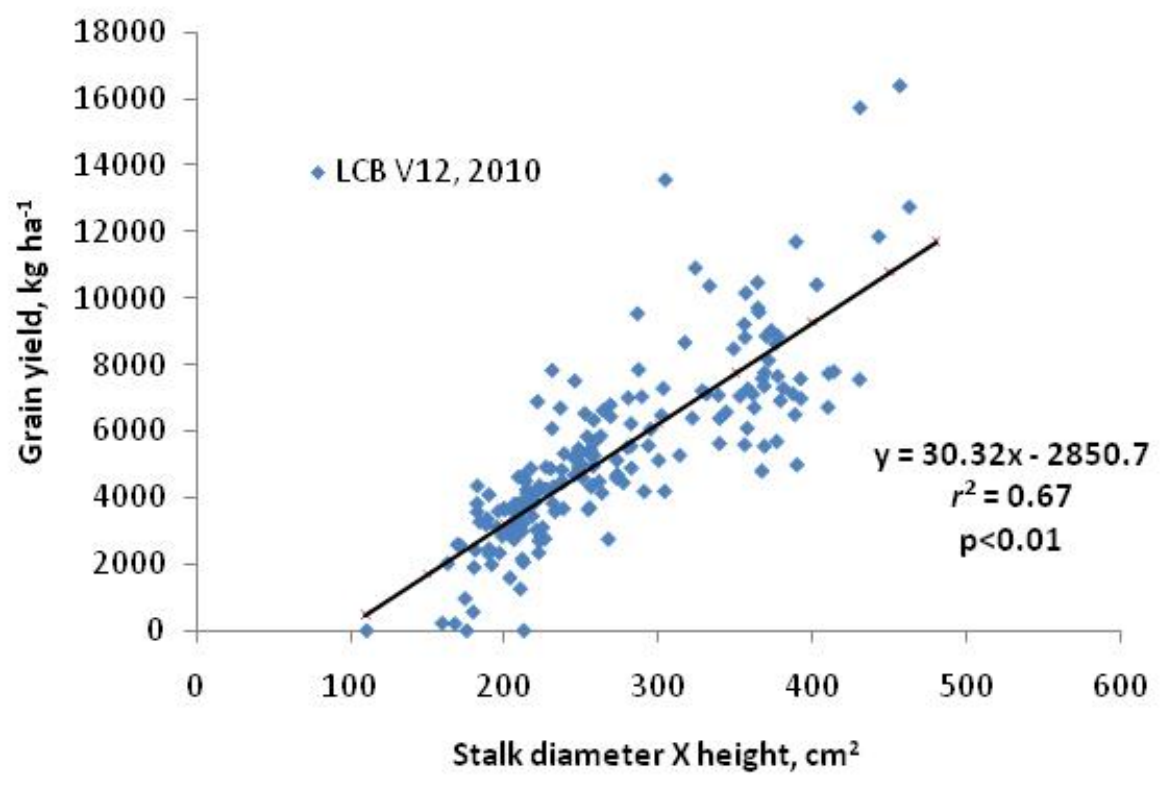

Fig. 10. Relationship between stalk diameter $X$ height and by-plant corn grain yield, growth stage V12, Lake Carl Blackwell, 2010. 


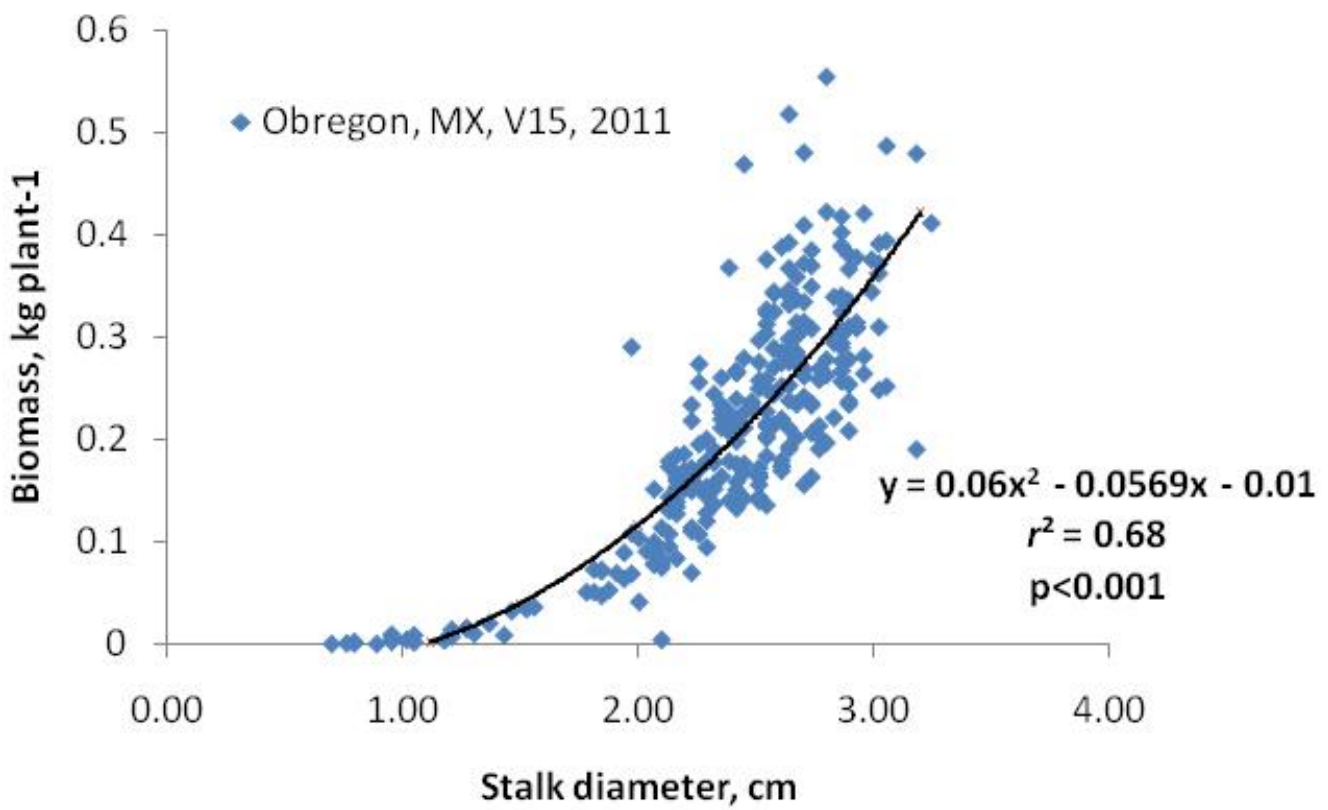

Fig. 11. Relationship between stalk diameter and by-plant corn biomass, growth stage V15, Ciudad Obregon, Mexico, 2011. 

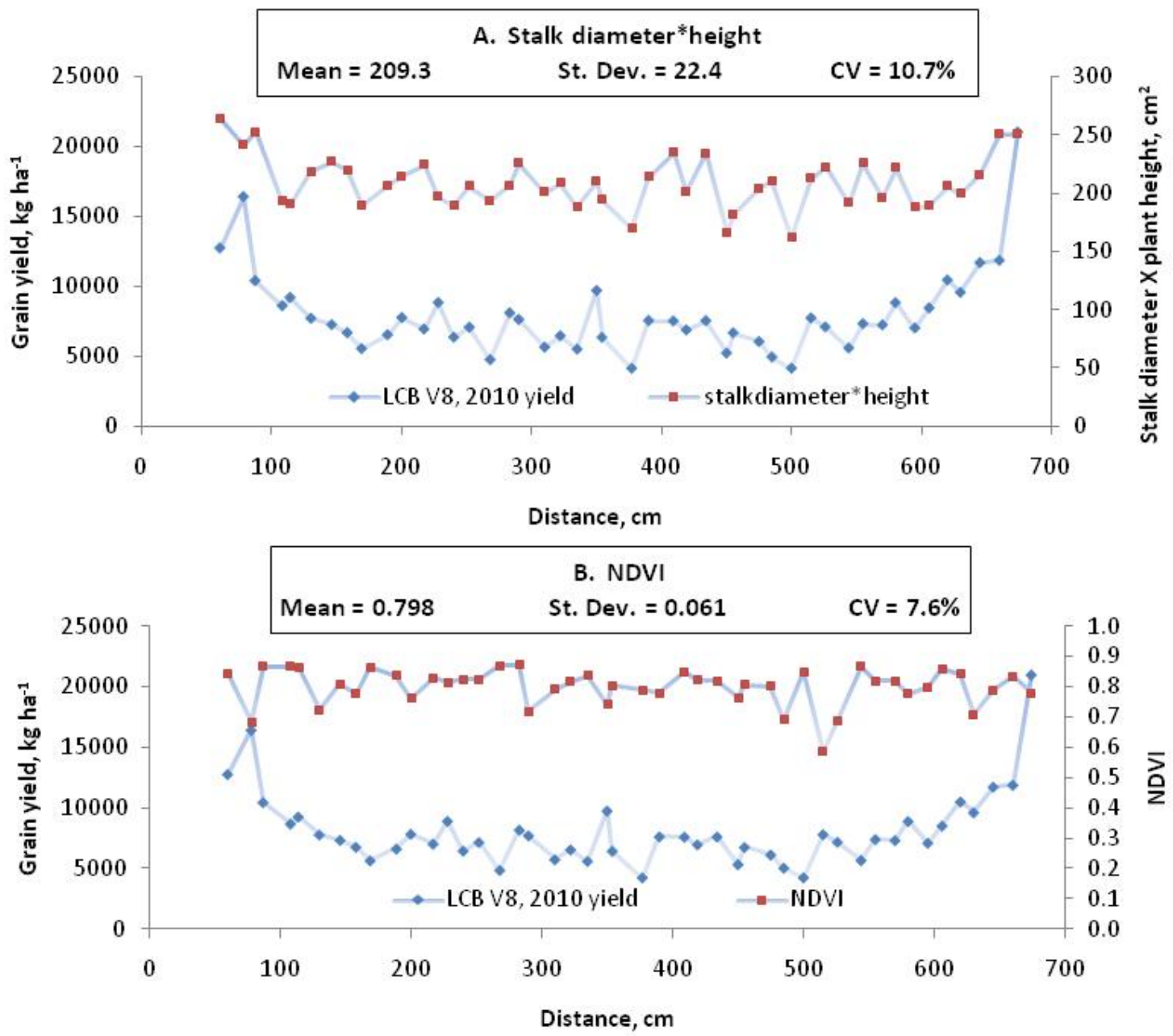

Fig. 12. Stalk diameter $X$ plant height $(A)$ and NDVI (B), as compared to by-plant corn grain yield by distance down the row. Lake Carl Blackwell, growth stage V8, 2010. 

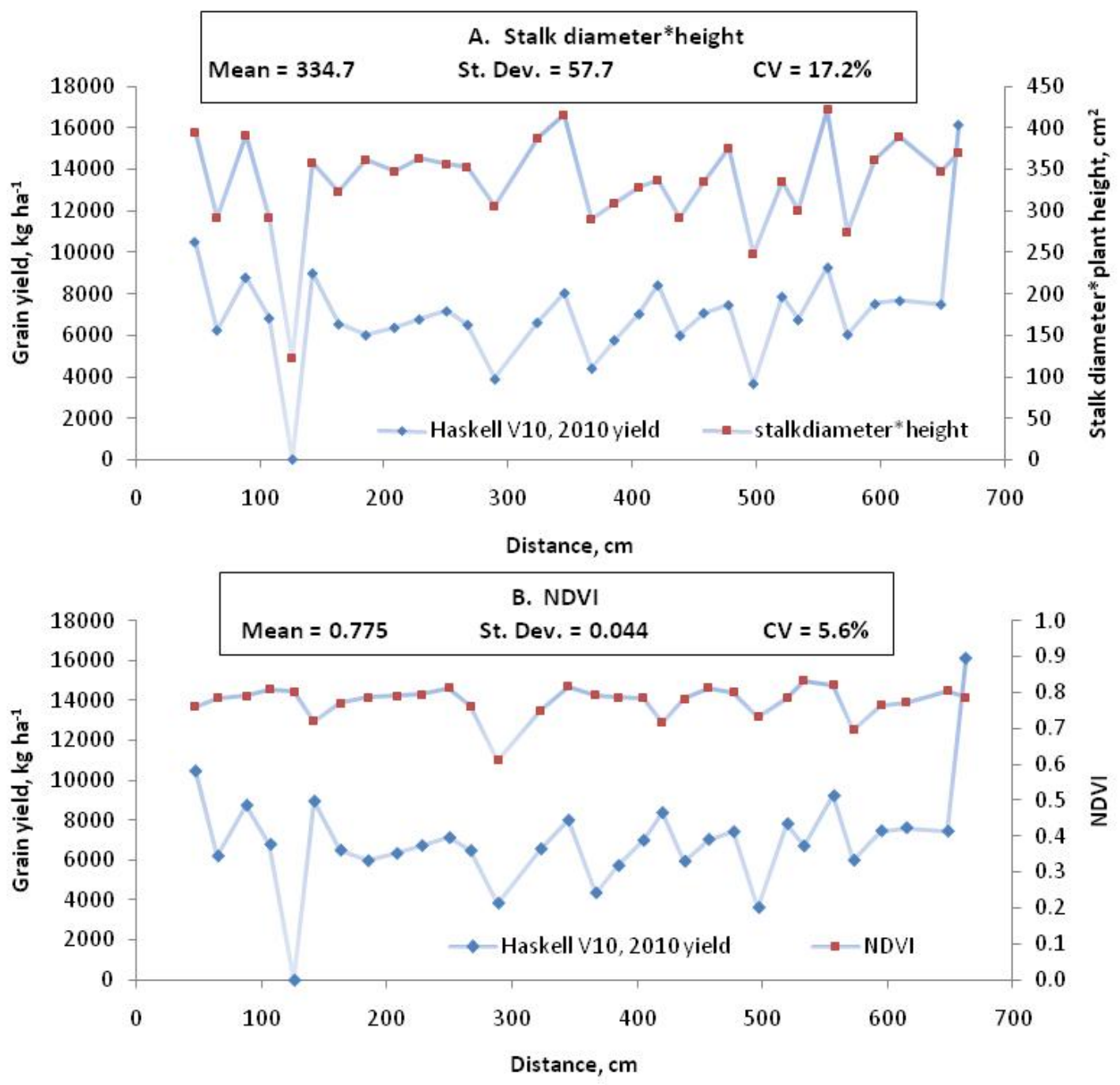

Fig. 13. Stalk diameter X plant height (A), and NDVI (B), as compared to by-plant corn grain yield by distance down the row. Haskell, growth stage V10, 2010. 
VITA

Jonathan Perry Kelly

Candidate for the Degree of

Master of Science

Thesis: BY PLANT PREDICTION OF CORN (Zea mays L.) GRAIN YIELD USING HEIGHT AND STALK DIAMETER

Major Field: Plant and Soil Sciences

Biographical:

Personal Data: Born in Altus, OK, on February 21, 1986, the son of Joe and Marsha Kelly.

Education: Graduated Valedictorian from Altus High School, Altus, OK, in 2004. Graduated Summa Cum Laude from Western Oklahoma State College with an Associate of Art in 2006. Graduated Summa Cum Laude with a Bachelor of Science in Natural Resource Ecology and Management and Plant and Soil Sciences at Oklahoma State University, Stillwater, OK in 2009. Completed the requirements for the Master of Science in Plant and Soil Sciences at Oklahoma State University, Stillwater, Oklahoma in May, 2011.

Experience: Raised on a cotton and wheat farming operation in Southwest Oklahoma, where employed as a summer-time farm laborer. Employed by Oklahoma State University Department of Natural Resource Ecology and Management for two summers, 2007-2008, as an undergraduate research assistant. Worked as an undergraduate research assistant in the Department of Plant and Soil Sciences under Dr. Bill Raun starting December 2008, and became a graduate research assistant in May 2009. Presently working as Senior Agriculturalist, Soil Fertility Project, Department of Plant and Soil Sciences, since August 2009.

Professional Memberships: American Society of Agronomy, Crop Science Society of America, and Soil Science Society of America. 
Title of Study: BY PLANT PREDICTION OF CORN (Zea mays L.) GRAIN YIELD USING HEIGHT AND STALK DIAMETER

Pages in Study: 36

Candidate for the Degree of Master of Science

Major Field: Plant and Soil Sciences

Scope and Method of Study: Current methodologies for determining midseason nitrogen $(\mathrm{N})$ rates in corn have used Normalized Difference Vegetation Index (NDVI), and in some cases, plant height and intra-specific plant competition. Another parameter that can be linked to potential yield is stalk diameter; thus incorporating collectively the parameters of NDVI, plant height, and stalk diameter should result in a better prediction of yield potential. This could lead to more efficient methods of midseason fertilizer $\mathrm{N}$ applications. The objective of this study is to analyze the relationship of stalk diameter, as well as plant height and NDVI, with final grain yield, and to refine the method of predicting yield potential using a combination of these factors. In this 2-year study at 4 locations, several rows of corn plants were selected, each with varying amounts of pre-plant nitrogen fertilizer, from 0 to $145 \mathrm{~kg} \mathrm{ha}^{-1}$, with no additional nitrogen inputs throughout the growing season. Measurements on plant spacing, stalk diameter, plant height, and NDVI were taken from growth stages V8 (eight fully collared leaves) to VT (corn tasselling), and all corn plants were harvested by-plant to determine grain yield or dry biomass.

Findings and Conclusions: Individual plant height measurements proved to be a good predictor of by-plant grain yield $\left(r^{2}=0.52,0.53 ; \mathrm{V} 10, \mathrm{~V} 12\right.$, respectively). Using a value of stalk diameter $\mathrm{X}$ plant height gave the best correlation with grain yield on an area basis $\left(r^{2}=0.34,0.55,0.67 ; \mathrm{V} 8, \mathrm{~V} 10, \mathrm{~V} 12\right.$, respectively). By-plant biomass was also predicted well by stalk diameter, with an $r^{2}$ value of 0.68 at growth stage V15, using a polynomial function. This research indicates that other factors besides NDVI can be used to predict by-plant corn grain yields, and stalk diameter $\mathrm{X}$ plant height may be the best method to use for refining midseason fertilizer $\mathrm{N}$ rates at growth stages $\mathrm{V} 8$ to $\mathrm{V} 12$.

ADVISER'S APPROVAL: Dr. William Raun 